\title{
Teachers' Perceptions of the Communicative Language Approach at a Saudi University
}

\author{
Ozma Siddiqui (Corresponding author) \\ English Language Institute, King Abdulaziz University \\ Jeddah, Saudi Arabia \\ Tel: 966-50-832-7594Ｅ-mail: ozma_siddiqui@hotmail.com
}

Fariha Asif

English Language Institute, King Abdulaziz University

Jeddah, Saudi Arabia

Tel: 966-55-013-0207Ｅ-mail: farihaa83@yahoo.com

\author{
Received: January 13, 2018 Accepted: January 31, 2018 Published: February 2, 2018 \\ doi:10.5296/ijele.v6i1.12579 URL: https://doi.org/10.5296/ijele.v6i1.12579
}

\begin{abstract}
The Communicative Language Teaching (CLT) approach has been widely popular in foreign language classrooms for a number of decades, but in recent years some practitioners have begun questioning the technique which prioritizes fluency over accuracy. This paper aims to record the perceptions of teachers using CLT to teach English as a foreign language at a Saudi university. It will also take into consideration some of the pitfalls and make some recommendations. A total of 35 participants, all members of faculty took part in the study. A mixed methods approach was used to collect the data. A questionnaire provided the statistical data for the study and semi-structured interviews were used to gather qualitative data. The statistical information was run through the SPSS. The findings indicate that while a substantial number of teachers at this university find the CLT approach a useful way to teach English to homogenous groups of Arabic speaking students, there is a need to be eclectic and incorporate other approaches for effective teaching.
\end{abstract}

Keywords: CLT approach, functional/notional, EFL/non-native, students' performance, language competency 


\section{Introduction}

The communicative language teaching approach has its origins in the British educational system dating from the late 1960s. Communicative language teaching (CLT) replaced the situational language teaching approach where English was taught by practicing basic structures in meaningful situation-based activities. British linguists at the time raised the question of addressing the functional and communicative dimension of language. They realized the need to focus on communicative proficiency rather than on mere mastery of structures.

The notion of language taught for communicative competence was furthered by Hymes, 1972 cited in (Johnstone and Marcellino, 2010). Hymes disagreed with Chomsky's idea of linguistic competence and his failure to acknowledge linguistic variation. In a reaction to Chomsky, he advocated the teaching of language functions in the different social contexts it was used rather than a mere study of the language.

Considering the widespread influence of Chomsky's theory of linguistic competence on foreign language teaching today, Hymes' critique of the theory makes for a compelling argument for the implementation of classroom techniques which prioritize fluency over accuracy embodied in the communicative language teaching approach. Fluency is essentially characterized by the ability to 'produce language easily and smoothly' while accuracy is described as being able to 'produce correct sentences using correct grammar and vocabulary (Scott, 2017). In the current context where there are a homogenous group of Arabic speaking students with little exposure to the English language, it has become pertinent to teach English quickly and effectively. This move is supported and driven by government policies to teach English in Saudi Arabia with the aim of having Saudis interact with foreign visitors who frequently come to the Kingdom on religious visits or for business and trade. These visitors speak English in the main besides their own language. As the number of visitors has steadily increased over the years, owing to the expansion of the two holy mosques and changes in foreign policy enabling more flexibility in business deals with the Kingdom, there is a greater understanding of the need for the local populace to be able to communicate fluently in the English language. Responding to this need, the Kingdom has invested heavily in English language programs in its institutes of higher education ensuring that qualified native speakers and near native teachers provide the correct models for English. In-house trainings are held all year round and teachers updated with the latest techniques equipping them with the necessary knowledge and classroom expertise. Yet, large numbers of students continue to face difficulties with learning the English language and are unable to pass the mandatory exams with high grades. This is particularly obvious in written exams such as reading and writing which require a high degree of accuracy calling to question the wholesale implementation of the communicative language teaching approach. It is this background that makes for a rationale to further explore the approach as it is being implemented at this university.

\subsection{Purpose of Study and Research Questions}

The study was made with the aim to examine the perceptions of teachers about CLT with 
regards to the issues that students at this university are faced with in the complex skills of reading, writing and vocabulary including grammatical concepts.

The students are taught English as a foreign language at the preparatory level. With a curriculum which encompasses the four levels ranging from elementary to intermediate levels corresponding to levels B, B1, A and A1 of the CEFRL(Common European Framework of Reference for Languages), (AlGhamdi and Siddiqui, 2016)students are regularly placed in their respective levels through a placement test. It has been observed that as students progress through the modules, students express increasing difficulty with reading, writing, vocabulary and grammar. As writing is a highly complex activity which requires accuracy, formatting for different purposes such as writing emails to a friend, requesting for leave and so on, and varied use of vocabulary, it becomes the single most challenging skill in the language.

The curriculum delivered through a communicative approach emphasizes fluency over accuracy and therefore, in recent years, students have expressed some satisfaction in speaking and listening skills. Grammar skills have been incorporated into the curriculum but they do not for the most part integrate with the writing activities. Teachers are therefore faced with the task of trying to help students use sentences meaningfully in paragraphs which put together would make a coherent and cohesive piece of writing with a logical line of thought running throughout.

There are also concerns that the communicative approach does not help with academic reading and writing skills and that the functional/notional items such as time, duration, quantity, location, around which the syllabus is designed is inadequate for students who are continuing to do advanced studies using English as the medium of instruction. However, these concerns are beyond the scope of this study although they do point to an important aspect of English language studies in the Preparatory or Foundation Year.

This paper will examine the effectiveness of the CLT approach, with specific reference to the context in which it is being implemented.

\subsection{Research Questions}

The paper will seek to address the following research questions:

i. Is the CLT approach effective?

ii. What are teachers' expectations and perceptions of the approach at this university?

iii. Are other approaches being used to complement the CLT?

\section{Review of Related Literature}

David Nunan, (1991) defined the CLT context as one where learners learn to communicate through interacting in the second language; use authentic texts; focus not only on the language but also on the learning process itself; where the personal experience of the learner is part of the learning process; and learners attempt to activate language use outside the 
classroom in real life contexts. Most importantly, learners are assessed on their communicative competence rather than on their knowledge of grammar rules. Communicative competence is defined as the ability to 'use the language for meaningful communication' (Richardson, 2006).

One of the strongest proponents of CLT was Dell Hymes (1972). He objected to the Chomskyan view that children are born with an innate set of skills for linguistic competence and that when given the right learning environment, they would acquire the language naturally. Chomsky believed that there were certain aspects of language which are uniform across speakers and focused on homogenous groups of language speakers. Hymes, on the other hand was interested in the actual linguistic variety found in speech and calls for 'concepts and methods that enable us to deal with diversity' making a case for communicative competence.

'Within the social matrix in which it acquires a system of grammar, a child acquires also a system of its use,' (Hymes, 1974: 75 cited in Johnstone and Marcellino, 2010). Hymes defined this system of use as communicative competence, his alternative to linguistic competence. 'Educators recognized the need for speaking proficiency rather than reading comprehension, grammar, or literary appreciation as the goal of foreign language programs'. (Richards and Rogers, 1999)

This need arose due to the changing socio-political climate where large scale immigration was taking place from former colonies to the host countries and governments realized the urgency of integration of these new arrivals on home soil. The most obvious way was to first teach them the English language and new ideas were being experimented with, among which the foremost was the CLT.

The aim of teaching using the CLT approach is primarily to enhance communication and develop communicative skills. Widdowson (1979) maintains that communication also takes place in situations which allows learners to use language 'to make statements of different kinds to describe, to record, to classify, to ask questions, make requests, give orders..'

While the CLT approach has been widely embraced in the Arab context, particularly in institutes of higher education, learners have a propensity to rote learn language materials. This is not restricted to grammar concepts but also reading passages. They may also memorize writing pieces wholesale from internet sites. There is a cultural aspect to memorization which is a valued trait in this part of the world. Rote learning is deeply ingrained into the systems of learning owing partly to the prevalence of religious teachings in schools which are learnt by heart. The other factor is the teaching of the English language at secondary and post-secondary levels where students are taught fixed phrases, reading and writing passages which they commit to memory and then reproduce for their exams. The cognitive skills in the higher band of Bloom's taxonomy (1956) such as application, analysis, evaluation and creativity are seldom arrived at with regards to the English language.

However, at university level, when students attempt to apply their memorization skills to the foreign language classroom they are faced with overwhelming difficulties posed by the CLT 
approach which does not encourage rote learning. It is therefore not uncommon to see students express confusion and dissatisfaction with the teaching-learning system in their foundation year.

Jan Anderson (1993) in his paper entitled "Is a Communicative Approach Practical for teaching English in China? Pros and Cons" shows the issues that Chinese students have with the approach which share several similarities with the Saudi context. It is succinctly pointed out that while CLT may work very well in most contexts, it may not be so successful with students who are studying English for different purposes and 'who have no desire to adopt our culture'(Anderson, 1993).

\subsection{Teachers' Perceptions and expectations about CLT}

Most teachers of English as a foreign language believe that CLT is a way of teaching learners communicatively in the second language with an emphasis on listening and speaking skills and little focus on grammar and writing skills. In an interview of ten teachers of Japanese in Australia conducted by Sato and Kleinsasser (cited in Littlewood, 2013) it was revealed that most of them thought that CLT meant spending a lot of time in preparing materials and getting learners to communicate with each other. But the reality was that they mostly had teacher-led classrooms with few opportunities for learners to interact with them or amongst each other.

This pertinent fact actually defeats the purpose of CLT which purports to be learner oriented and reveals that different teachers have different views on what actually constitutes the CLT approach.

Findings of a study conducted at a Kuwaiti university by Shu-hua Wu and SulaimanAlrabah, (2014) "Tapping the Potential of Skill Integration as a Conduit for Communicative Language Teaching"(cited in Alwazir and Shukri, 2017) revealed that while teachers used skills integration techniques in their classrooms, they were hesitant to apply it wholesale owing to the demands of tests and exams modelled on traditional patterns of assessing the accuracy of grammar rules instead of fluency in the target language.

However, it was discovered that when learners' language proficiency is improved, rote memorization is significantly reduced (Alwazir and Shukri, 2017). The CLT approach should ideally contain activities which are meaningful leading to authentic language but the reality is that while this works very well for skills such as speaking, students flounder when they are asked to produce pieces of writing which require a high degree of accuracy. Indeed, this has been one of the biggest criticisms of CLT: that accuracy is compromised in favor of fluency (Harmer, 2007 cited in Alwazir and Shukri).

Although CLT focuses mainly on the use of the language rather than its mechanics, there are some critiques which question the concept of accuracy as we commonly understand it.

According to Jenny Scott (2017), 'the concept of accuracy is relative'. A child for example, will not be able to acquire the same level of accuracy as an adult and where accuracy is emphasized, the aim is to 'help students produce grammatically correct written and spoken 
English' to the level of a native speaker of that age. Fluency on the other hand, requires learners to speak effortlessly without pauses despite mistakes which are often disregarded.

In most cases and particularly at this university, teachers help to instil accuracy through grammar exercise practice, speaking presentations and so on while fluency is promoted by role play, group activities and such like where 'English is used as a medium of communication rather than an end in itself'. (Scott, 2017)

However, it is a point of contention as to which is more important: accuracy or fluency. Teachers with a traditional view of teaching believe that accuracy is more important and given that students typically sit for formal assessments where accuracy is necessary, this view seems logical. On the other hand, fluency counts a great deal towards communicating a message for a purpose. (Scott, 2017) So while students brought up on 'accuracy' may be adept at doing grammar exercises, they may be lost for words to make a reservation for a flight on the phone, for example. On the other hand, the speech of students who can converse fluently may contain gross errors in both speaking and writing.

It is possible to see accuracy and fluency along a continuum with accuracy at one end and fluency at the other. Beginners who have no experience of the language may start off with learning accurate spelling, grammar forms and functions. At the pre-intermediate level, they may be introduced to debates and discussions which call for more fluency. In contrast, younger children are often introduced to fluency activities such as nursery rhymes first and then gradually progress towards tasks which demand more accuracy.

In all, the merits of the CLT approach cannot be denied and when compared to the traditional methods of teaching such as the grammar-translation and audio-lingual methods for example, the interactive approach involving information gap activities for real life situations (role plays) do create the environment for the eliciting of authentic language.

\subsection{Challenges of the CLT Approach}

Perhaps the biggest challenge is the large number of classes and limited resources. Teachers fear the lack of classroom management and managing pair and group work in classes with large numbers of learners. Although, the ideal number is $10-15$ per group, classes typically comprise 25-30 students at this university. While the CLT approach encourages interaction, foreign language learners do not have enough target language to begin with and often end up using their native language. Syllabi are often taught progressively item by item instead of holistically contrary to the CLT approach. Teachers commonly take it upon themselves to impart knowledge rather than act as a guide or facilitator. Most importantly, exams are based on discrete items rather than on communication alone.

Chow \& Mok-Cheung ((2004) cited in Littlewood, 2013)) define the change from teacher-led classrooms to the CLT approach as a "quantum leap" which is also the case in Saudi Arabia. Both the teaching and learning context required for CLT is very new and vastly different from what they are used to. Teachers are now faced with the task of adapting and creating materials; change the way they teach, change the way they assess; use technology and shift from teacher-centered to learner-oriented classrooms. Furthermore, they now have to focus on both 
communicative as well as linguistic competence. It is a given that where there are challenges, teachers will be faced with certain limitations as to how much they can actually accomplish in the classroom. This is one of the factors which has given impetus to this study.

\section{Methodology}

Due to the exploratory nature of this study, the empirical design was based on teachers' observations and first-hand experience of the CLT approach. The data was drawn over a period of three months or two modules of a semester. The students are in the foundation or preparatory year and are homogenous speakers of Arabic. Convenience sampling (Bogden \& Biklen, 1998 cited in $\mathrm{Wu}$ and Alrabah, 2014) consisted of 35 full time female faculty members at this university teaching English as a foreign language. Data for this study were collected in two ways: via semi-structured interviews conducted with 5 volunteers who provided the qualitative data to open ended questions and a questionnaire comprising 10 questions on a likert scale regarding various aspects of CLT as it is being implemented at this university.

The objectives behind the data collection via a mixed methods approach were manifold: firstly to get a brief overview of teachers' thoughts and perceptions of CLT through semi-structured interviews. Questions range from general themes drawn from various aspects of CLT such as whether teachers find the CLT approach effective to more specific with regards to materials, grammar and vocabulary items, teaching of receptive or productive skills first, and role play, group and pair work. Responses to the questionnaire provided the quantitative data for the study which was analyzed using the SPSS software. However, since the study explores teachers' perceptions of CLT, the data is based on their observations of the CLT approach and leans more to the qualitative than quantitative aspect.

The data for the interviews was collected from five teachers teaching English as a foreign language at this university. Data for the quantitative data were obtained via a set of 10 questions on a likert scale distributed electronically among 30 members of faculty. The questions based on various aspects give a comprehensive view of teachers' perceptions of the CLT approach.

The 35 participants are of different nationalities with up to 7-10 years of experience in EFL instruction. The data was collected in the second semester of the academic year (March-May 2016) in the female section of this university.

\section{Findings}

In the first data collection obtained through semi-structured interviews, all the five participants have different views on the effectiveness/ineffectiveness of the CLT approach. None are prepared to debunk the approach in its entirety but all agree that there is a gap which needs to be addressed for the approach to be more effective. 
"Firstly, I don't think it's an ineffective teaching approach and secondly, a teacher has to have fair knowledge of CLT approach and know how and when to use it." (Participant A)

The idea that teachers require more training in the use of the CLT approach is iterated by Participant F:

"I strongly believe that there are many factors that lead to the effectiveness or ineffectiveness of CLT approach at the ELI. These factors run the gamut from learners'level of motivation to teachers'level of proficiency and knowledge to the ELI educational policy."

The educational policy is in question by Participants G:

"I want to point to the fact that time constraint and abiding by curriculum and pacing guide may prevent a teacher from implementing a truly communicative class."

And Participant $\mathrm{H}$ :

"The underlying problem stems from the modular system, which has resulted in teachers trying to cram in the "highlights" (i.e. what's likely to be tested) in the short time available. Students do not have time to digest the material before they are moved on to the next level, so each subsequent level becomes more frustrating for them and their teachers."

At least one participant disagrees with the approach completely stating:

"How can one expect students to have language competency through teaching some exchanges of the language and practicing them without understanding the basics, the origins, the conjugations..etc. of the whole exponent?" (Participant R)

All participants except one agrees that stand alone grammar and vocabulary lists are not useful for language learning or even acquisition. However, they are considered essential 'tools' (Participant R) without which language cannot be accessed.

Again, all participants agree that receptive and productive skills are complementary while at least one participant holds that it is the natural order of learning a language.

The use of authentic materials is generally thought to be advantageous for learners although two participants feel that they need to be adapt them to learners' needs in certain contexts so that they are motivated to continue learning English:

"If the curriculum is focused on general English for everyday situations, then most authentic material would have to be adapted to some extent... What would be more effective is using authentic material students are likely to be exposed to in their other university classes (i.e. academic texts) so that they see a need to learn English". (Participant H)

And Participant R:

"Authentic or non -authentic..the materials have to cater to the students' needs, prior knowledge and language proficiency levels."

Participants were encouraged to voice their opinions on the use of role play, etc. which is central to the CLT approach aiming to elicit authentic language from learners. 
Participant A thinks that learning fixed sentences and phrases in a real life situation to convey a message is insufficient for acquisition to take place:

The purpose of learning a language is not just to communicate for everyday needs but also to express thoughts and ideas. In that case the above mentioned topics for role play seem to be more formal and might not be fun to all learners.

This is repeated in Participant R's response:

"..teaching some exponents and practicing them in the form of role plays or group work even if the activities given are pseudo-realistic."

While Participant H says:

"We teach in an EFL setting, where students are unlikely to need to carry out these functions in English. Students may be able to "communicate (i.e. others may understand what they are trying to say), but they need other approaches if they are to succeed in using English in an academic setting."

With the precept that CLT does not adopt an academically inclined curriculum, focusing instead on communicative activities, the last question was meant to elicit responses which would provoke ideas on supplementing the approach with an academically oriented syllabus. Participants have some suggestions as to how this could be implemented.

Participant $\mathrm{G}$ felt that it is possible to combine the CLT approach with academic activities through the think-pair-share strategy:

"First, students are given time to think of a certain topic. Second, they are asked to formulate ideas and share them with a partner. Third, the teacher writes students' responses on the board which will later serve as prompts for producing essays on that topic."

Participant $\mathrm{H}$ believes that some skills could be adapted to include an academic curriculum:

“...listening can include listening to a lecture and taking notes and speaking should include some presentation skills, rather than making a reservation at a restaurant. For students going on to majors where English is the nominal language of instruction and assessment, including a more academic focus to reading and writing instruction would be beneficial."

\section{Results and Discussion}

One of the main aims of the study is to take an overview of teachers' perceptions of the CLT approach as it is being implemented at this university and their expectations. The study was undertaken with the understanding that the participants would find the approach lacking and that they would make certain recommendations which would have far reaching effects on pedagogical practices, learners' motivation and their performance in terms of language competency. While the results support this view, the overall outlook is that the CLT approach is currently one of the preferred approaches among others to implement in EFL (English as a Foreign Language) classrooms. 
In the Questionnaire, the first five questions used in the interviews were circulated again but among a different group of participants. According to the table, questions 2-13 registered a high score with the mean percentage ranging from approximately 50-86 percent. This shows that there are mixed views about the CLT approach as it is being implemented at this university. Curiously, questions 1 and 14 showed an average score of 50 and 56 percent respectively. While the average score for question 1 (vocabulary lists and grammar forms) is understandable given the stand alone nature of the exercises, question 14 (the need to produce CLT oriented materials) is surprising. Where some participants had voiced the need for more training in the CLT approach which would have been enhanced by CLT oriented materials, the average score of $56 \%$ seems to be contradictory. Indeed, materials which can be adapted to suit CLT are needed in order to train teachers on how to use them. This again reflects the mixed perceptions about the CLT approach.

The pie chart clearly shows that $41 \%$ of the 30 participants who took part in the study agree that the CLT approach was ineffective while only $27 \%$ strongly agreed. However, $18 \%$ were neutral, while $9 \%$ disagreed and only $5 \%$ strongly disagreed that the approach was ineffective.

With a view to the research questions, it can be said that firstly, teachers' expectations of the CLT approach as a 'complete' system to teach English effectively is lacking in some respects as observed by the data above. With reference to the first hypothetical question on whether the CLT approach is effective, it is interesting to note from the data that while questions are raised about relying completely on the approach as a comprehensive teaching tool, it is still considered quite useful and practical. That said, it is perhaps appropriate to take the important fact into consideration that 'teachers need to adapt CLT to suit specific contexts' (Littlewood, 2013).

While the notional/functional element of the language is considered an advantage, merely teaching fixed phrases for real life situations is deemed insufficient. With students' propensity to use memorization as a learning strategy, (Oanh and Hien, 2006), it is even more challenging to get them to produce authentic language. However, tutors' views regarding rote learning are similar to the experience of the Vietnamese teachers wherein the strategy is not disregarded completely. In fact, teachers are vividly aware of its potential value as a learning strategy 'provided that (it) is used appropriately to help students internalize what they have learnt in actual communication'. With regards to the second question, (teachers' perceptions and expectations of CLT) the data shows mixed views with some leaning in favor and some against with a small number who are neutral. This indicates that the CLT approach is suitable in as far as the objective of communicating in English is concerned. As far as this aim is concerned, teachers' expectations of the approach are in line with the goals of the language course. With regards to the third research question which explored whether other approaches are being used, it is revealed that teachers freely supplement their lessons with the grammar translation method, direct method and whole classroom teaching with teacher-led classrooms, especially with low proficient students. This latter group of students can also expect to receive some instruction and explanation in the first language. This shows that teachers are both eclectic in their approach and flexible with teaching methods and 
supplementing materials as the need arises. The results reflect previous studies which support the positive attitude of teachers towards the CLT approach in general and with particular reference to teaching in groups (Rahimi \& Naderi, 2014).

\section{Limitations}

The study has a number of limitations. Firstly, the sample of participants was small with only 35 teachers in total. Secondly, the responses are only taken from the female section at the university.

\section{Conclusion and Recommendations}

The findings reveal mixed reviews about the CLT approach as it is being implemented at this university. While most agree that teaching phrases and pieces of language is insufficient for a better understanding of the English language, the functional/ notional element of conveying a message for a certain purpose is certainly accomplished using this approach. It has to be taken into account at the outset that the communicative syllabus as taught at this university is not bereft of grammar skills. But concerns have been raised regarding the stand-alone nature of the grammar exercises which do not automatically translate into academic reading and writing activities.

It may be worthwhile to note that if academic skills are incorporated, teachers will have to plan new strategies to teach effectively via the CLT approach. On the other hand, teachers can be helped to develop principles which would help them to form a communication oriented language teaching approach (COLT) or adapt the CLT to suit their specific context, (Littlewood, 2013). Another consideration could be greater use of technology to promote academic reading and writing skills. An academically oriented curriculum would also be of much benefit recognizing the need for advanced English courses for students who are going on to do their majors in the English language or use it as the medium of instruction in other subjects.

\section{Implications for future studies}

Some important conclusions can be arrived at from this study. Firstly, suitable use of authentic materials is thought to engage students' interest in the subject. The only reservation is that finding 'suitable' authentic materials and adapting them to learners' needs is a tedious process and it is far simpler to teach from the course book. Secondly, combining the CLT approach with academic reading and writing skills would be a welcome move recognizing students' need to use the medium of the English language for instruction in advanced studies and in future careers.

E-learning platforms such as black board and the use of mobile learning applications would also greatly enhance student engagement and learner autonomy. Perhaps the most important conclusions are firstly, the need to train instructors to use the CLT approach and secondly, to have an academic oriented curriculum which also combines elements of the communicative language oriented approach. 


\section{Ml Macrothink}

This study clearly reveals a gap in the guidelines of the CLT approach and its practice. While CLT is learner-centred, the large numbers of students usually means that teachers are doing more classroom management than actual teaching. Policy makers, educationists and the main stakeholders, the students themselves would all benefit from the findings which point out the practical need for a more academic curriculum to be taught at this university and other institutes of higher education. More studies need to be conducted in incorporating an academically inclined curriculum which could lead to a gradual shift from EFL to ESL learning. There is also scope for studying the implementation of this shift in the current context where students are aspiring for higher education through English as a medium of instruction. Professionals and experts in the field may therefore consider designing a curriculum with this shifting paradigm in mind.

\section{Acknowledgement}

I would like to thank my colleagues and members of the Student Academic Support Committee at the King Abdulaziz University, English Language Institute to help collect the data for this study in terms of their perceptions and views of the CLT approach as they implement it in their classrooms.

\section{References}

Alghamdi, F., \& Siddiqui, O. (2016). Supporting Low-achieving EFL Learners: Expectations, Procedure and Significance of Remedial Sessions at a Saudi University. http://dx.doi.org/10.11114/jets.v4il2.2028

Alwazir, B., \& Shukri, N. (2017). The use of CLT in the Arab Context: A critical perspective ( $1^{\text {st }}$ ed.). International Journal of English Language. http://dx.doi.org/10.5296/ijele.v5il.10486

Anderson, J. (1993). Is a Communicative Approach Practical for Teaching English in China? Pros and Cons. http://dx.doi.org/10.1016/0346-251X(93)90058-O

Johnstone, B., \& Marcellino, W. (2010). Dell Hymes and the Ethnography of Communication.

Littlewood, W. (2013). Developing a Context sensitive Pedagogy for Communication oriented Language teaching. Retrieved from https://koreatesol.org/sites/default/files/pdf/Littlewood

Nunan, D. (1991). Communicative Tasks and the Language Curriculum. http://dx.doi.org/10.2307/3587464

Oanh, D., \& Hien, N. (2006). Memorization and EFL Students' Strategies at University Level in Vietnam. Retrieved from http://www.cc.kyoto-su.ac.jp/information/tesl-ej/ej38/a4.html 


\section{Macrothink}

Rahimi, M., \& Naderi, F. (2014). The relationship between EFL Teachers' Attitudes towards CLT and Perceived Difficulties of Implementing CLT in Language Classes. Retrieved from http://www.journals.aiac.org.au/index.php/IJALEL/article/view/1081

Richards, J. (2006). Communicative Language Teaching Today. New York: Cambridge University Press. Retrieved from https://faculty.mu.edu.sa/public/uploads/1347871288.356924906420-Jack-C-Richards-Comm unicative-Language-Teaching-Today.pdf

Scott, J. (2012). Accuracy vs Fluency in TEFL. Retrieved from http://www.icaltefl.com/accuracy-vs-fluency-in-tefl

Widdowson, H. (1979). The Teaching of English as Communication. In C. Brumfit and K. Johnson (Eds.), The Communicative Approach to Language Teaching, Oxford: Oxford University Press. Retrieved from http://si-lang.inf.uth.gr/index.php?title=Communicative_Approach_to_Language_Teaching_a nd_Learning

Wu, Shu-hua, \& Alrabah, Sulaiman. (2014). Tapping the Potential of Skill Integration as a Conduit for Communicative Language Teaching. http://dx.doi.org/10.5539/elt.v7n11p119

\section{Glossary}

CLT: Communicative Language Teaching

CEFRL: Common European Framework of Reference for Languages

COLT: Communicative Oriented Language Teaching

EFL: English as a Foreign Language

ESL: English as a Second Language

\section{Appendices}

\section{Appendix 1.}

1. The CLT approach as it is being implemented at the ELI is ineffective in helping learners acquire language competency.

\begin{tabular}{|c|l|c|c|c|c|c|}
\hline$\#$. & \multicolumn{1}{|c|}{ Statement } & N & $\begin{array}{c}\text { Std } \\
\text { Dev }\end{array}$ & Mean & $\begin{array}{c}\text { Mean } \\
\%\end{array}$ & $\begin{array}{c}\text { Mean } \\
\text { Level }\end{array}$ \\
\hline 1. & $\begin{array}{l}\text { The CLT approach as it is being implemented at the } \\
\text { ELI is ineffective in helping learners acquire } \\
\text { language competency. }\end{array}$ & 30 & 1.31 & 2.50 & $50 \%$ & Average \\
\hline
\end{tabular}




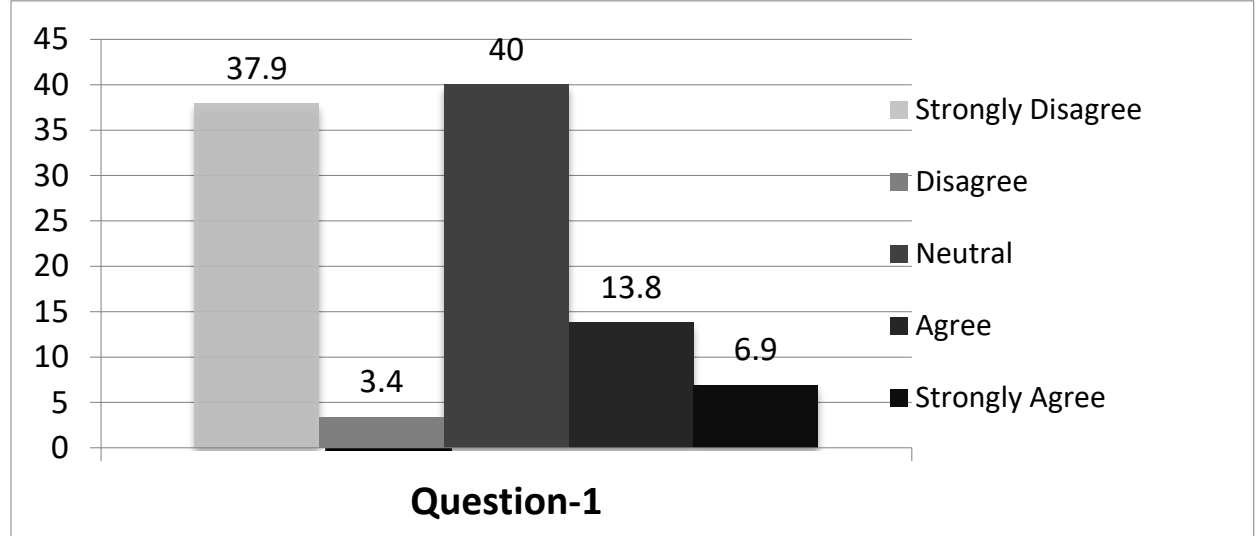

2. More focus on providing vocabulary lists and grammar forms would help learners improve language competency.

\begin{tabular}{|l|l|c|c|c|c|c|}
\hline$\#$. & \multicolumn{1}{|c|}{ Statement } & N & $\begin{array}{c}\text { Std } \\
\text { Dev }\end{array}$ & Mean & $\begin{array}{c}\text { Mean } \\
\%\end{array}$ & $\begin{array}{c}\text { Mean } \\
\text { Level }\end{array}$ \\
\hline 2. & $\begin{array}{l}\text { More focus on providing vocabulary lists and grammar } \\
\text { forms would help learners improve language } \\
\text { competency. }\end{array}$ & 30 & 0.94 & 3.47 & $69 \%$ & High \\
\hline
\end{tabular}

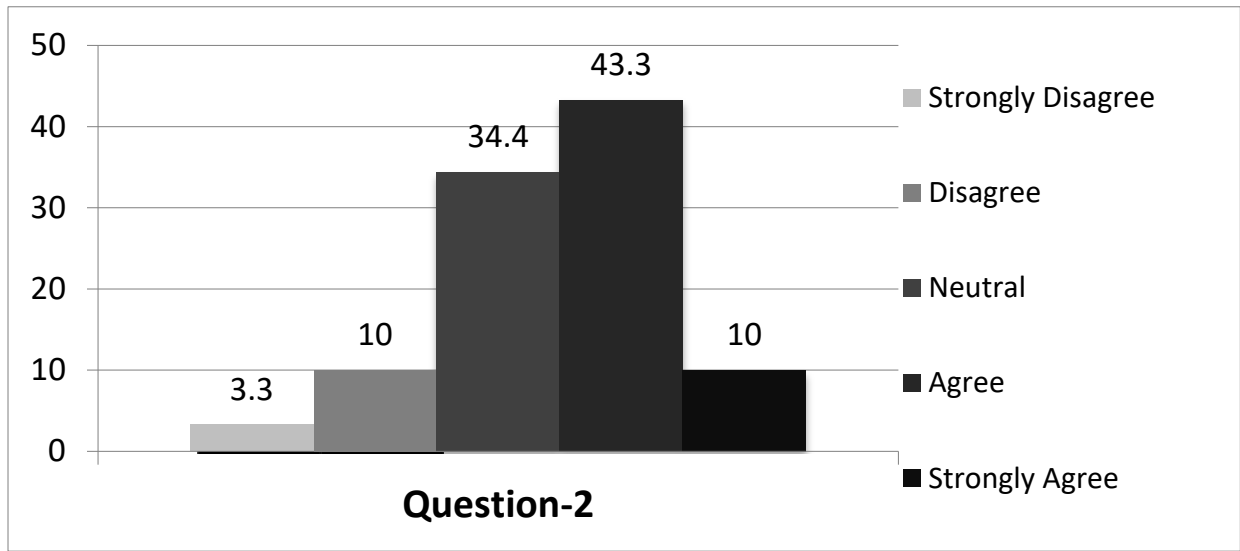

3. It is better for receptive skills (reading and listening) to be taught before productive ones (speaking and writing)?

\begin{tabular}{|l|l|l|l|l|l|l|}
\hline$\#$. & \multicolumn{1}{|c|}{ Statement } & N & $\begin{array}{l}\text { Std } \\
\text { Dev }\end{array}$ & Mean & $\begin{array}{c}\text { Mean } \\
\%\end{array}$ & $\begin{array}{c}\text { Mean } \\
\text { Level }\end{array}$ \\
\hline 3. & $\begin{array}{l}\text { It is better for receptive skills (reading and listening) to } \\
\text { be taught before productive ones (speaking and } \\
\text { writing)? }\end{array}$ & 30 & 1.01 & 3.57 & $71 \%$ & High \\
\hline
\end{tabular}




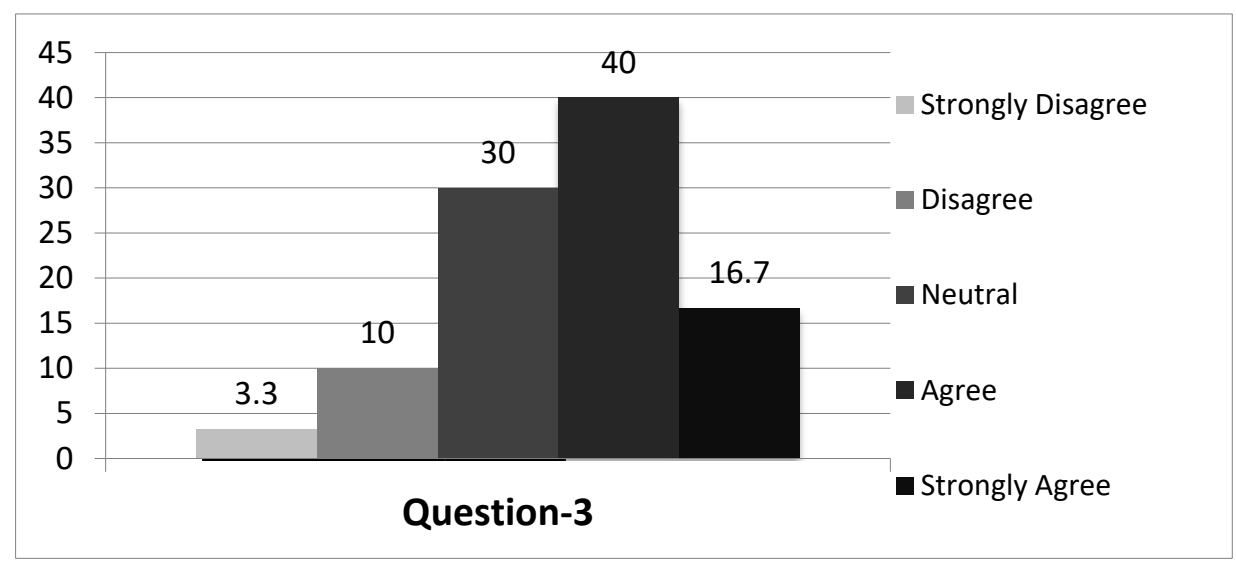

4. Suitable use of authentic materials increases learners' motivation to learn English.

\begin{tabular}{|l|l|c|c|c|c|c|}
\hline \#. & \multicolumn{1}{|c|}{ Statement } & N & $\begin{array}{c}\text { Std } \\
\text { Dev }\end{array}$ & Mean & $\begin{array}{c}\text { Mean } \\
\text { \% }\end{array}$ & $\begin{array}{c}\text { Mean } \\
\text { Level }\end{array}$ \\
\hline 4. & $\begin{array}{l}\text { Suitable use of authentic materials increases learners' } \\
\text { motivation to learn English. }\end{array}$ & 30 & 0.88 & 4.30 & $86 \%$ & High \\
\hline
\end{tabular}

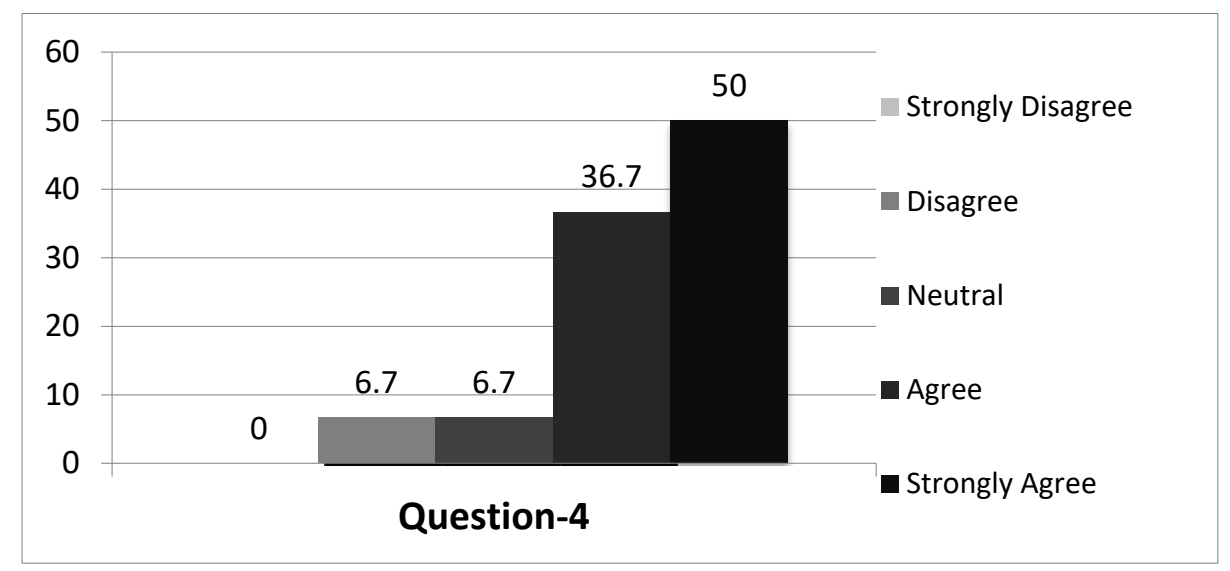

5. Role plays, group work, real life contexts and functional language (language used for a purpose like making a reservation, booking a flight, making an order at a restaurant) are sufficient for learners to achieve language competency. 


\begin{tabular}{|l|l|c|c|c|c|c|}
\hline$\#$. & \multicolumn{1}{|c|}{ Statement } & N & $\begin{array}{c}\text { Std } \\
\text { Dev }\end{array}$ & $\begin{array}{c}\text { Mean } \\
\text { 5. }\end{array}$ & $\begin{array}{c}\text { Mean } \\
\text { \% }\end{array}$ & $\begin{array}{c}\text { Mean } \\
\text { Level }\end{array}$ \\
\hline $\begin{array}{l}\text { Role-plays, group work, real life contexts and functional } \\
\text { language (language used for a purpose like making a } \\
\text { reservation, booking a flight, making an order at a } \\
\text { restaurant) are sufficient for learners to achieve language } \\
\text { competency. }\end{array}$ & 1.07 & 3.53 & $71 \%$ & High \\
\hline
\end{tabular}

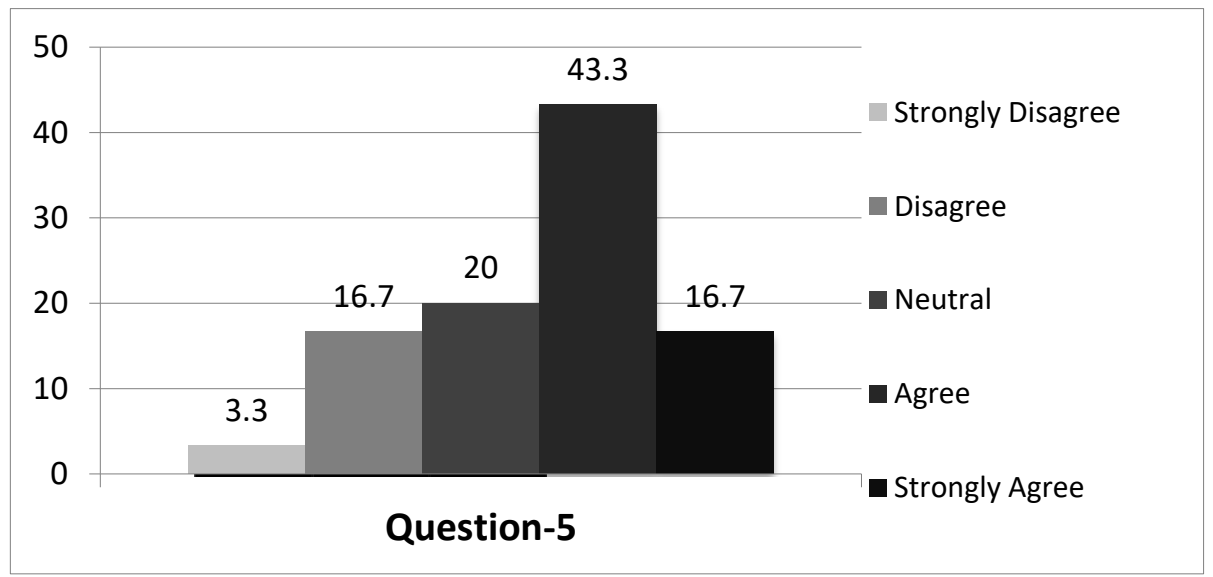

6. Would learners benefit from the CLT being combined with academic writing skills?

\begin{tabular}{|l|l|c|c|c|c|c|}
\hline$\#$. & \multicolumn{1}{|c|}{ Statement } & N & $\begin{array}{c}\text { Std } \\
\text { Dev }\end{array}$ & Mean & $\begin{array}{c}\text { Mean } \\
\text { \% }\end{array}$ & $\begin{array}{c}\text { Mean } \\
\text { Level }\end{array}$ \\
\hline 6. & $\begin{array}{l}\text { Would learners benefit from the CLT being combined } \\
\text { with academic writing skills? }\end{array}$ & 30 & 0.79 & 4.00 & $80 \%$ & High \\
\hline
\end{tabular}

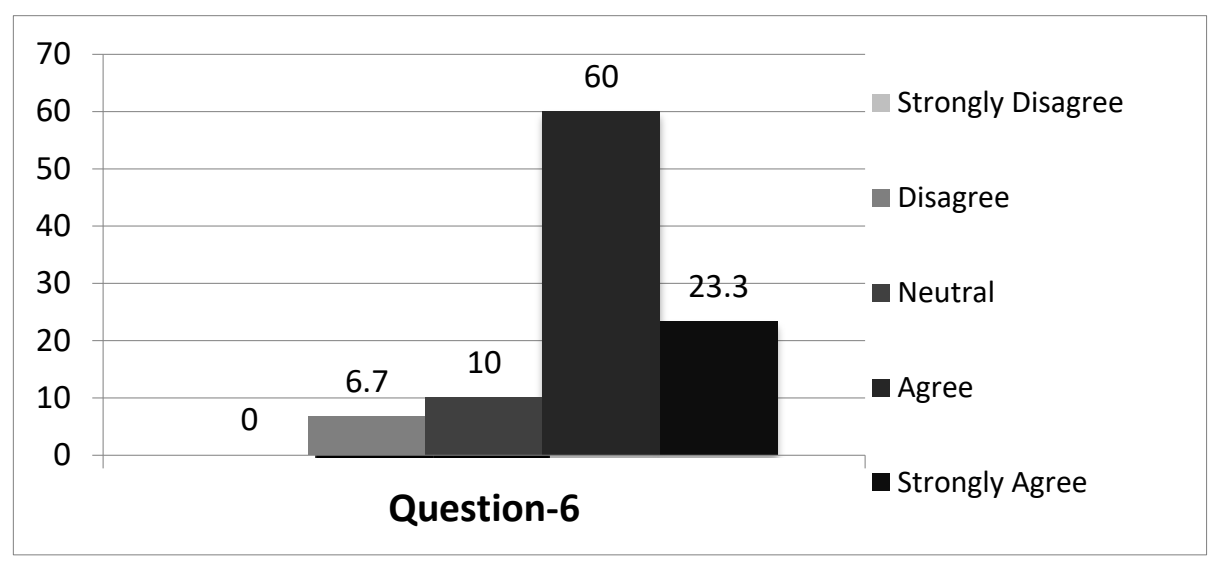


7. Learners should be encouraged to learn language skills rather than theoretical knowledge of the language system.

\begin{tabular}{|l|l|c|c|c|c|c|}
\hline$\#$. & \multicolumn{1}{|c|}{ Statement } & N & $\begin{array}{c}\text { Std } \\
\text { Dev }\end{array}$ & Mean & $\begin{array}{c}\text { Mean } \\
\text { \% }\end{array}$ & $\begin{array}{c}\text { Mean } \\
\text { Level }\end{array}$ \\
\hline 7. & $\begin{array}{l}\text { Learners should be encouraged to learn language skills } \\
\text { rather than theoretical knowledge of the language } \\
\text { system }\end{array}$ & 30 & 0.85 & 4.03 & $81 \%$ & High \\
\hline
\end{tabular}

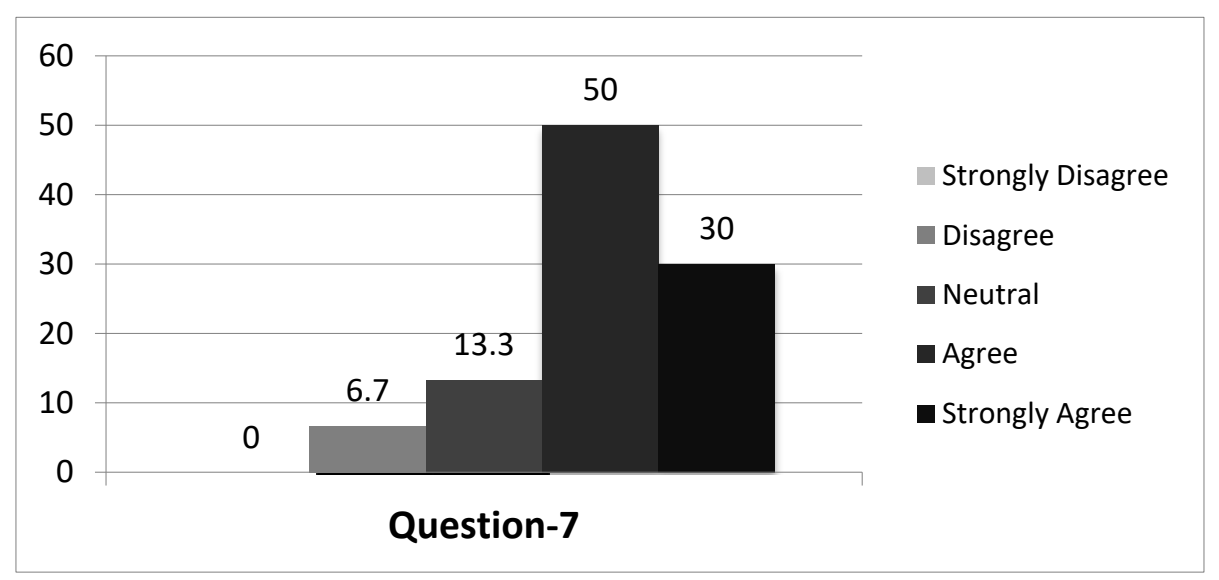

8. Peer learning can facilitate communication among learners.

\begin{tabular}{|l|l|c|c|c|c|c|}
\hline \#. & \multicolumn{1}{|c|}{ Statement } & N & $\begin{array}{c}\text { Std } \\
\text { Dev }\end{array}$ & \multicolumn{1}{|c|}{ Mean } & $\begin{array}{c}\text { Mean } \\
\text { \% }\end{array}$ & $\begin{array}{c}\text { Mean } \\
\text { Level }\end{array}$ \\
\hline 8. & $\begin{array}{l}\text { Peer learning can facilitate communication among } \\
\text { learners. }\end{array}$ & 30 & 0.83 & 4.27 & $85 \%$ & High \\
\hline
\end{tabular}

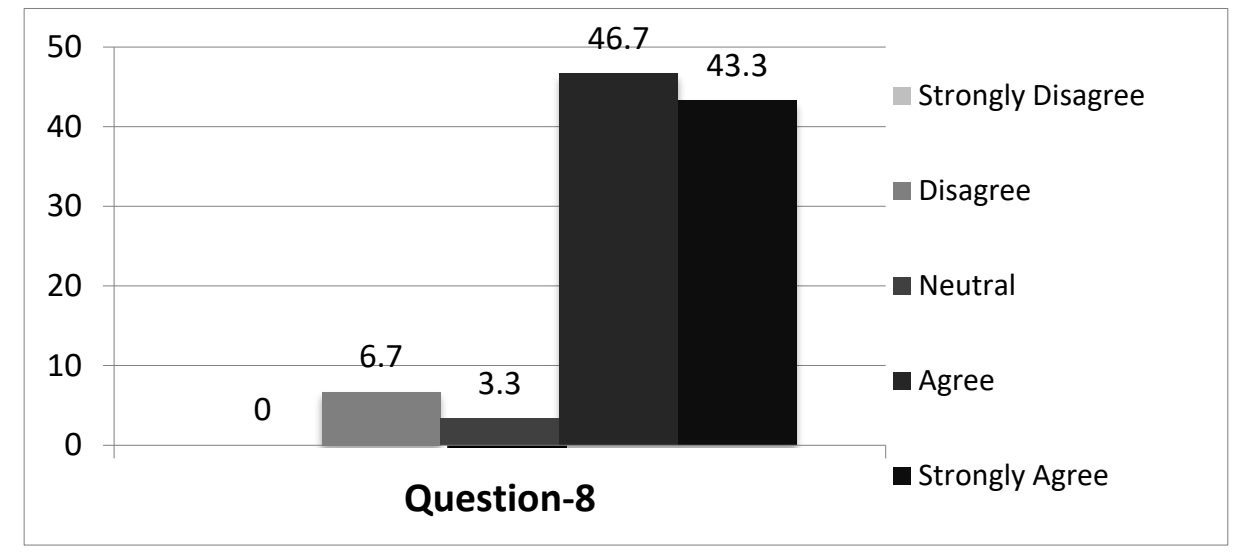

9. E-learning can be an interesting tool for listening and speaking. 


\begin{tabular}{|l|l|c|c|c|c|c|}
\hline$\#$. & \multicolumn{1}{|c|}{ Statement } & N & $\begin{array}{c}\text { Std } \\
\text { Dev }\end{array}$ & Mean & $\begin{array}{c}\text { Mean } \\
\%\end{array}$ & $\begin{array}{c}\text { Mean } \\
\text { Level }\end{array}$ \\
\hline 9. & $\begin{array}{l}\text { E-learning can be an interesting tool for listening and } \\
\text { speaking. }\end{array}$ & 30 & 0.89 & 4.03 & $81 \%$ & High \\
\hline
\end{tabular}

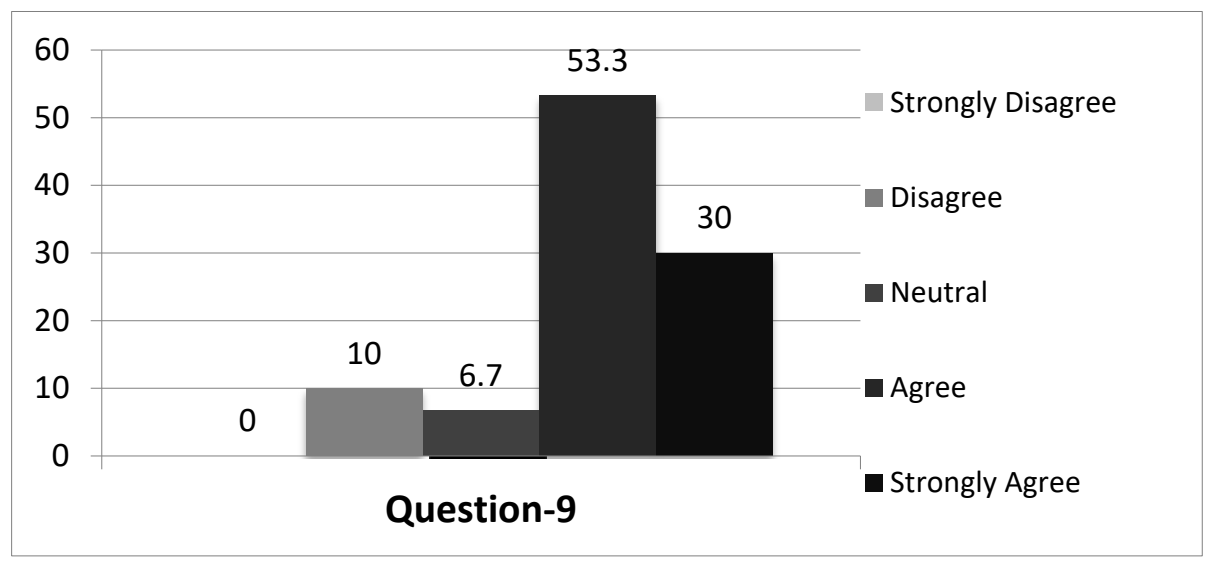

10. Mobiles can play an important role in the attainment of communication language aims.

\begin{tabular}{|c|l|c|c|c|c|c|}
\hline \#. & \multicolumn{1}{|c|}{ Statement } & N & $\begin{array}{c}\text { Std } \\
\text { Dev }\end{array}$ & \multicolumn{1}{|c|}{ Mean } & $\begin{array}{c}\text { Mean } \\
\text { \% }\end{array}$ & $\begin{array}{c}\text { Mean } \\
\text { Level }\end{array}$ \\
\hline 10. & $\begin{array}{l}\text { Mobiles can play an important role in the attainment of } \\
\text { communication language aims. }\end{array}$ & 30 & 0.94 & 3.87 & $77 \%$ & High \\
\hline
\end{tabular}

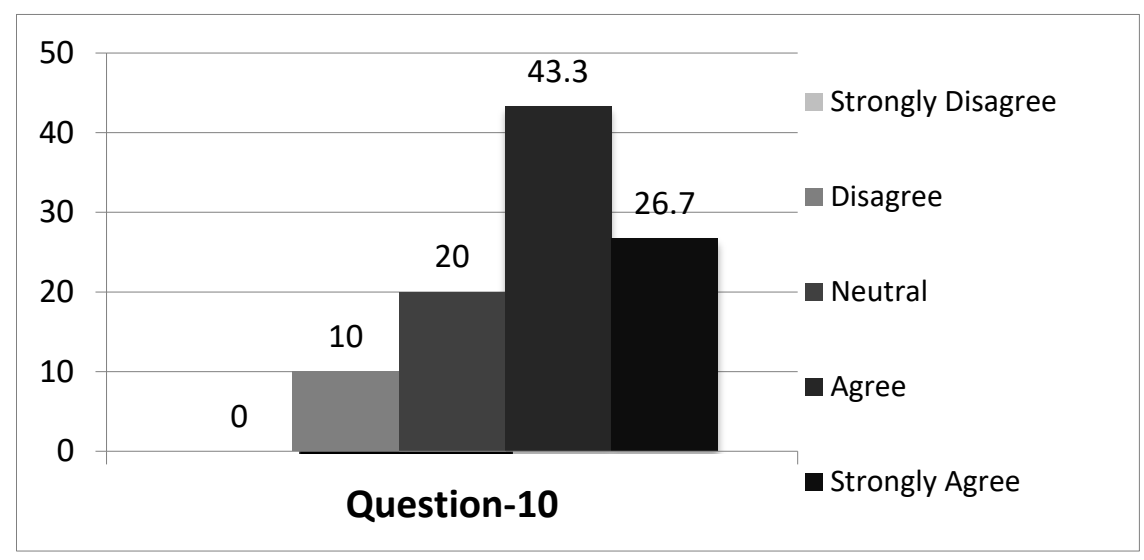


11. Teachers need to be trained to use the Communicative language teaching approach.

\begin{tabular}{|c|l|c|c|c|c|c|}
\hline \#. & \multicolumn{1}{|c|}{ Statement } & N & $\begin{array}{c}\text { Std } \\
\text { Dev }\end{array}$ & Mean & $\begin{array}{c}\text { Mean } \\
\%\end{array}$ & $\begin{array}{c}\text { Mean } \\
\text { Level }\end{array}$ \\
\hline 11. & $\begin{array}{l}\text { Teachers need to be trained to use the Communicative } \\
\text { language teaching approach. }\end{array}$ & 30 & 0.70 & 4.17 & $83 \%$ & High \\
\hline
\end{tabular}

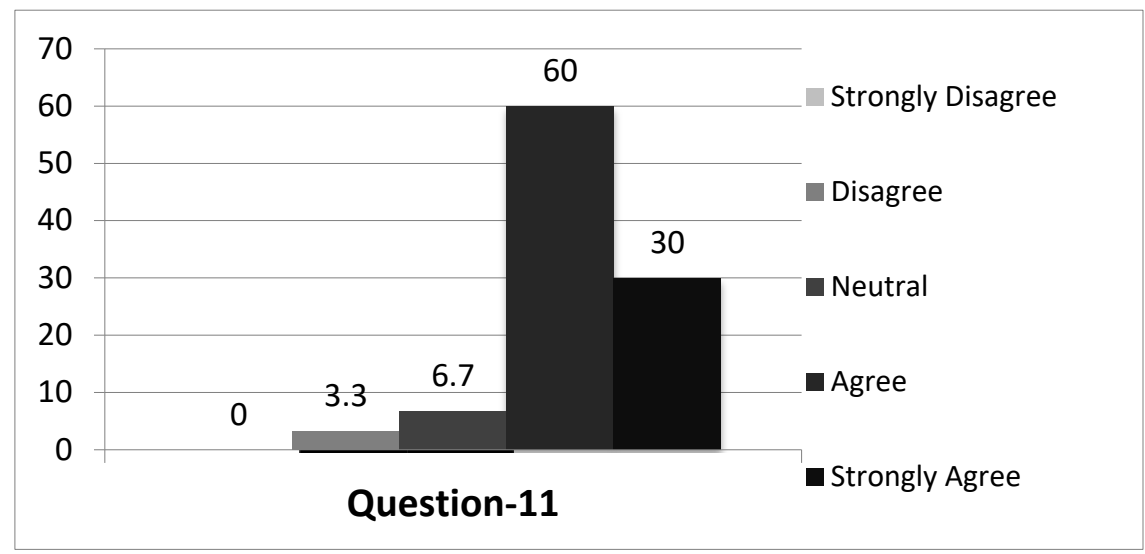

12. Classroom activities like discussions and debates can facilitate CLT.

\begin{tabular}{|c|l|c|c|c|c|c|}
\hline \#. & \multicolumn{1}{|c|}{ Statement } & N & $\begin{array}{c}\text { Std } \\
\text { Dev }\end{array}$ & \multicolumn{1}{|c|}{ Mean } & $\begin{array}{c}\text { Mean } \\
\text { \% }\end{array}$ & $\begin{array}{c}\text { Mean } \\
\text { Level }\end{array}$ \\
\hline 12. & $\begin{array}{l}\text { Classroom activities like discussions and debates can } \\
\text { facilitate CLT. }\end{array}$ & 30 & 0.94 & 4.23 & $85 \%$ & High \\
\hline
\end{tabular}

\begin{tabular}{|c|c|c|c|}
\hline \multirow[t]{2}{*}{50} & & 46.7 & \multirow[b]{2}{*}{ Strongly Disagree } \\
\hline & \multicolumn{2}{|r|}{40} & \\
\hline 30 & & & Disagree \\
\hline 20 & & & Neutral \\
\hline \multirow{2}{*}{10} & \multicolumn{2}{|c|}{10} & \\
\hline & 0 & 3.3 & Agree \\
\hline \multicolumn{3}{|c|}{ Question-12 } & - Strongly Agree \\
\hline
\end{tabular}


13. CLT can't be used in a mixed learning group.

\begin{tabular}{|c|c|c|c|c|c|c|}
\hline$\#$. & \multicolumn{1}{|c|}{ Statement } & N & $\begin{array}{c}\text { Std } \\
\text { Dev }\end{array}$ & Mean & $\begin{array}{c}\text { Mean } \\
\%\end{array}$ & $\begin{array}{c}\text { Mean } \\
\text { Level }\end{array}$ \\
\hline 13. & CLT can't be used in a mixed learning group. & 30 & 1.35 & 2.80 & $56 \%$ & Average \\
\hline
\end{tabular}

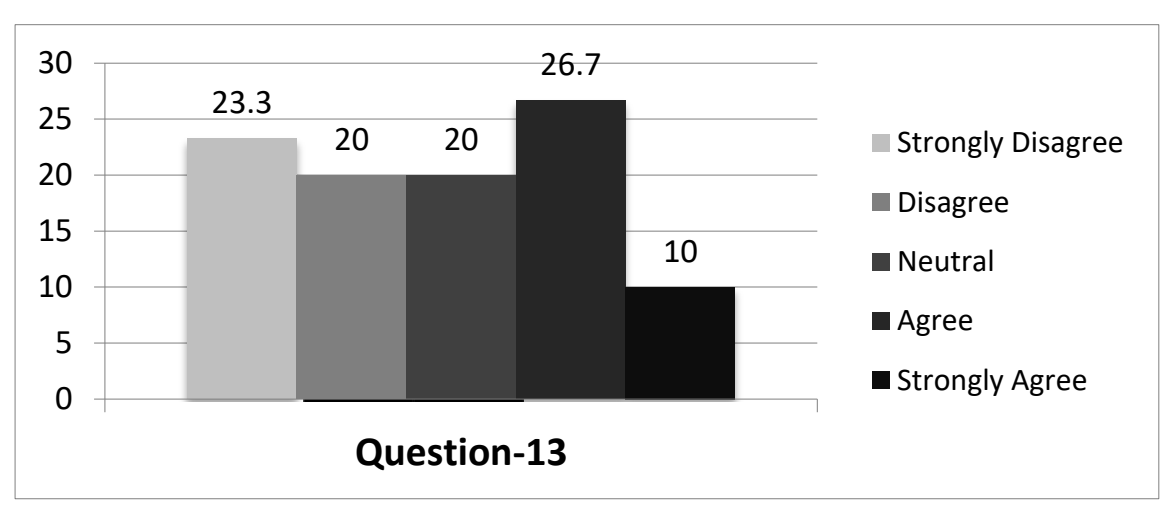

14. CLT needs appropriate textbooks to attain language objectives.

\begin{tabular}{|c|l|c|c|c|c|c|}
\hline$\#$. & \multicolumn{1}{|c|}{ Statement } & N & $\begin{array}{c}\text { Std } \\
\text { Dev }\end{array}$ & \multicolumn{1}{|c|}{ Mean } & $\begin{array}{c}\text { Mean } \\
\%\end{array}$ & $\begin{array}{c}\text { Mean } \\
\text { Level }\end{array}$ \\
\hline 14. & $\begin{array}{l}\text { CLT needs appropriate textbooks to attain language } \\
\text { objectives. }\end{array}$ & 30 & 1.10 & 3.63 & $73 \%$ & High \\
\hline
\end{tabular}

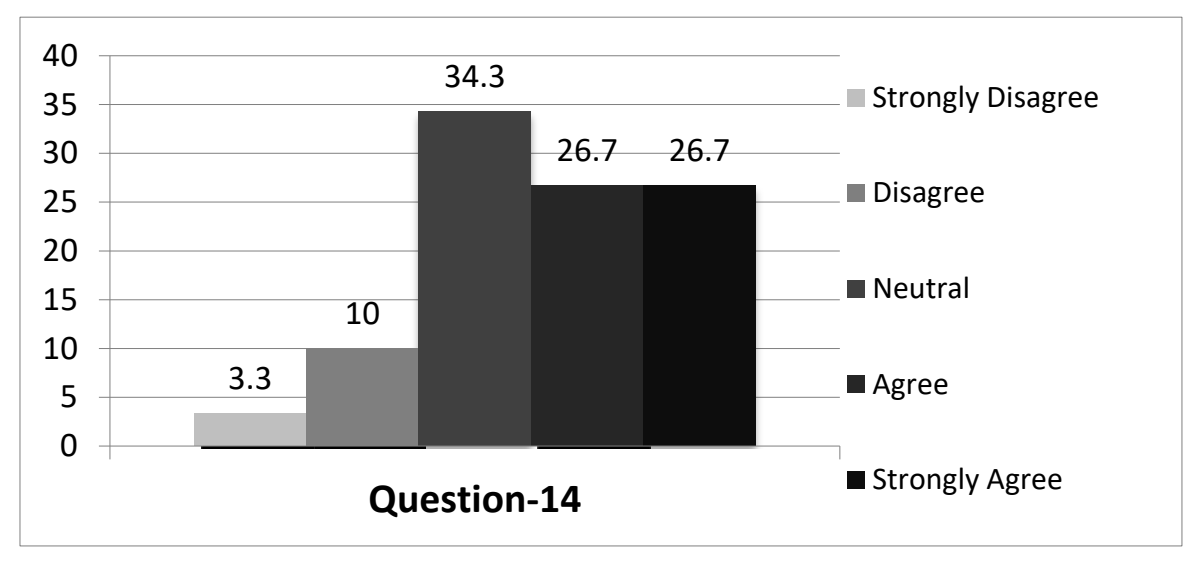

15. There is an urgent need to produce CLT oriented learning materials.

\begin{tabular}{|c|l|c|c|c|c|c|}
\hline$\#$. & \multicolumn{1}{|c|}{ Statement } & N & $\begin{array}{c}\text { Std } \\
\text { Dev }\end{array}$ & \multicolumn{1}{|c|}{ Mean } & $\begin{array}{c}\text { Mean } \\
\%\end{array}$ & $\begin{array}{c}\text { Mean } \\
\text { Level }\end{array}$ \\
\hline 15. & $\begin{array}{l}\text { There is an urgent need to produce CLT oriented } \\
\text { learning materials. }\end{array}$ & 30 & 0.95 & 4.00 & $80 \%$ & High \\
\hline
\end{tabular}




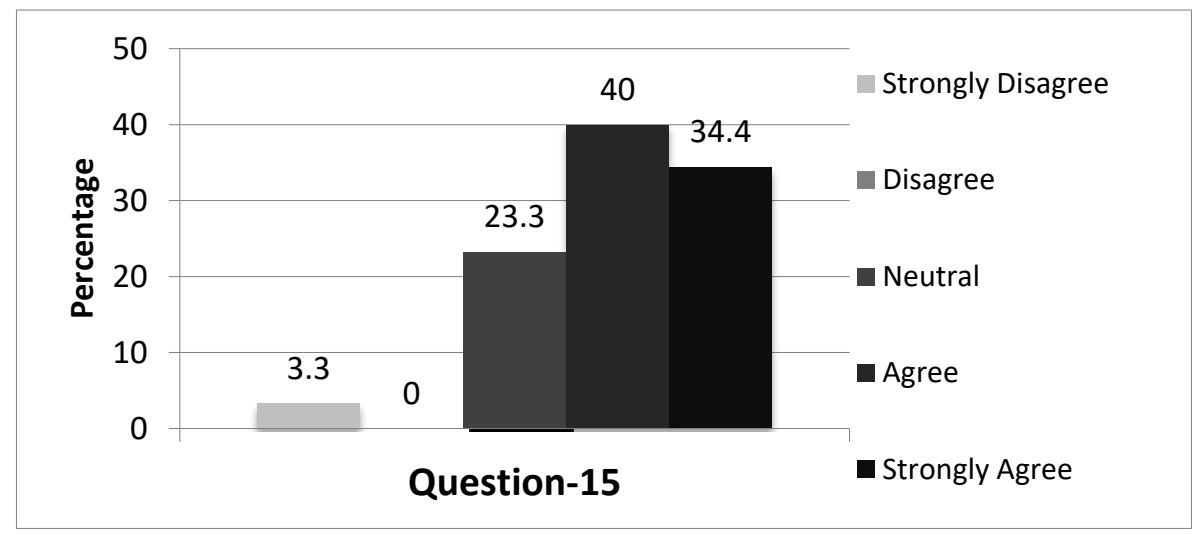

Appendix 2: Pie Chart

\section{Percentage: Strongly Disagree- Strongly Agree}

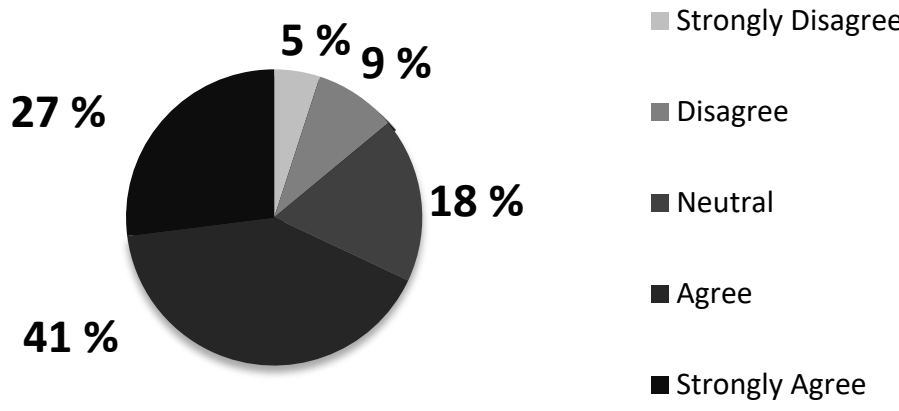

Appendix 3: Participant types

\begin{tabular}{|l|c|c|c|}
\hline Code & Age group & $\begin{array}{l}\text { Native } \\
\text { Arab }\end{array}$ & $\begin{array}{l}\text { Years of teaching experience in } \\
\text { EFL }\end{array}$ \\
\hline Participant A & $45-55$ & No & $7+$ \\
\hline Participant F & $35-40$ & Yes & $6+$ \\
\hline Participant G & $35-40$ & No & $7+$ \\
\hline Participant H & $55-60$ & No & $10+$ \\
\hline Participant R & $45-55$ & Yes & $9+$ \\
\hline
\end{tabular}


Appendix 4. Questionnaire for Teachers' Perceptions of the CLT Approach

\begin{tabular}{|l|l|}
\hline \multicolumn{1}{|c|}{ Theme } & \multicolumn{1}{|c|}{ Questions } \\
\hline $\begin{array}{l}\text { Effectiveness/ineffectiveness of the CLT } \\
\text { approach }\end{array}$ & $\begin{array}{l}\text { The CLT approach as it is being implemented } \\
\text { at the ELI is ineffective at helping learners } \\
\text { acquire language competency. What do you } \\
\text { think? }\end{array}$ \\
\hline Focus on grammar and vocabulary & $\begin{array}{l}\text { Do you think that more focus on providing } \\
\text { vocabulary lists and grammar forms would } \\
\text { help learners improve language competency? } \\
\text { Please give reasons. }\end{array}$ \\
\hline Receptive skills versus productive skills & $\begin{array}{l}\text { It is better for receptive skills (reading and } \\
\text { listening) to be taught before productive ones } \\
\text { (speaking and writing). Please say why. }\end{array}$ \\
\hline Usefulness of authentic materials & $\begin{array}{l}\text { Do you think that using authentic materials in } \\
\text { our context increase learners' motivational } \\
\text { levels to learn English? }\end{array}$ \\
\hline Usefulness of role play, pair work, etc. & $\begin{array}{l}\text { Are role play, group work, real life contexts } \\
\text { and functional language (language used for a } \\
\text { purpose like making a reservation, booking a } \\
\text { flight, making an order at a restaurant) } \\
\text { sufficient for learners to achieve language } \\
\text { competency? }\end{array}$ \\
\hline
\end{tabular}

\section{Appendix 5.}

\begin{tabular}{|c|c|c|c|c|c|c|}
\hline \#. & Statement & $\mathbf{N}$ & $\begin{array}{l}\text { Std } \\
\text { Dev }\end{array}$ & Mean & $\begin{array}{c}\text { Mean } \\
\%\end{array}$ & $\begin{array}{l}\text { Mean } \\
\text { Level }\end{array}$ \\
\hline 1. & $\begin{array}{l}\text { More focus on providing vocabulary lists and } \\
\text { grammar forms would help learners improve language } \\
\text { competency }\end{array}$ & 30 & 1.31 & 2.50 & $50 \%$ & Average \\
\hline 2. & $\begin{array}{l}\text { It is better for receptive skills (reading and listening) } \\
\text { to be taught before productive ones (speaking and } \\
\text { writing) }\end{array}$ & 30 & 0.94 & 3.47 & $69 \%$ & High \\
\hline 3. & $\begin{array}{l}\text { Suitable use of authentic materials increases learners' } \\
\text { motivation to learn English }\end{array}$ & 30 & 1.01 & 3.57 & $71 \%$ & High \\
\hline 4. & $\begin{array}{l}\text { Role plays, group work, real life contexts and } \\
\text { functional language (language used for a purpose like } \\
\text { making a reservation, booking a flight, making an } \\
\text { order at a restaurant) are sufficient for learners to } \\
\text { achieve language competency }\end{array}$ & 30 & 0.88 & 4.30 & $86 \%$ & High \\
\hline
\end{tabular}




\begin{tabular}{|l|l|l|l|l|l|l|}
\hline 5. & $\begin{array}{l}\text { Learners would benefit from the CLT being combined } \\
\text { with academic writing skills }\end{array}$ & 30 & 1.07 & 3.53 & $71 \%$ & High \\
\hline $\mathbf{6 .}$ & $\begin{array}{l}\text { Learners should be encouraged to learn language } \\
\text { skills rather than theoretical knowledge of the } \\
\text { language system }\end{array}$ & 30 & 0.79 & 4.00 & $80 \%$ & High \\
\hline 7. & $\begin{array}{l}\text { Peer learning can facilitate communication among } \\
\text { learners }\end{array}$ & 30 & 0.85 & 4.03 & $81 \%$ & High \\
\hline 8. & $\begin{array}{l}\text { E-learning can be an interesting tool for listening and } \\
\text { speaking }\end{array}$ & 30 & 0.83 & 4.27 & $85 \%$ & High \\
\hline 9. & $\begin{array}{l}\text { Mobiles can play an important role in the attainment } \\
\text { of communication language aims }\end{array}$ & 30 & 0.89 & 4.03 & $81 \%$ & High \\
\hline 10. & $\begin{array}{l}\text { Teachers need to be trained to use the Communicative } \\
\text { language teaching approach }\end{array}$ & 30 & 0.94 & 3.87 & $77 \%$ & High \\
\hline 12. & CLT can't be used in a mixed learning group & 30 & 0.70 & 4.17 & $83 \%$ & High \\
\hline $\mathbf{1 3 .}$ & $\begin{array}{l}\text { CLT needs appropriate textbooks to attain language } \\
\text { objectives }\end{array}$ & 30 & 0.94 & 4.23 & $85 \%$ & High \\
\hline $\mathbf{1 4 .}$ & $\begin{array}{l}\text { There is an urgent need to produce CLT oriented } \\
\text { learning materials }\end{array}$ & 30 & 1.35 & 2.80 & $56 \%$ & Average \\
\hline & & 30 & 0.97 & 3.76 & 0.75 & High \\
\hline
\end{tabular}

\section{Copyright Disclaimer}

Copyright for this article is retained by the author(s), with first publication rights granted to the journal.

This is an open-access article distributed under the terms and conditions of the Creative Commons Attribution license (http://creativecommons.org/licenses/by/3.0/). 